\author{
УДК 93/94 \\ http://doi.org/10.36906/KSP-2020/15
}

Сологуб Н.С.

Региональный историко-культурный и экологический центр («Экоцентр»)

2. Мегион, Россия

\title{
СИБИРЬ И СИБИРЯКИ В МЕМУАРАХ ДЕКАБРИСТОВ
}

Аннотация. На основе обширного мемуарного наследия ссыльных декабристов автор анализирует выдвигаемые ими концепции по отношению к Сибири и ее жителям в XIX веке. Статья характеризует положительные и негативные тенденции в развитии региона данного периода, отмеченные со стороны бывших дворян и революционеров. Приводится также попытка охарактеризовать прошлое и настоящее Сибири через призму колониального вопроса и возможных путей развития края.

Ключевые слова: Сибирь, декабристы, ссылка, мемуары, колонизация, каторга.

Мемуары сосланных в Сибирь декабристов представляют особую ценность для исследователя в связи с тем, что на современном этапе развития исторической науки происходит сдвиг от изучения истории процессов к истории в ее антропологической интерпретации. Исследователю интересен жизненный путь человека, его ментальность, отношение к событиям. В связи с этим, анализ источников личного происхождения позволяет по-иному прочесть "традиционные" представления русского человека о себе, своих соотечественниках, других народах.

Оказавшиеся в непривычной для них среде, при этом обладая хорошим образованием и прекрасными личностными качествами (наблюдательностью, трудолюбием, любовью к ближнему) декабристы оставили для нас независимые и объективные свидетельства о регионе, история которого в первой половине XIX в. крайне слабо обеспечена источниками личного происхождения. При этом мемуары дают возможность реконструировать различные аспекты жизни и деятельности сибиряков, которые не нашли отражение делопроизводственной документации. Причем многое они наблюдали не со стороны, не как заезжие путешественники и ученые, а глубоко проникнув в суть излагаемых ими вопросов.

Сибирь начала XIX в. была территорией, абсолютно обособленной для большей части населения Европейской России. Декабристы, также видели в ней глухой и забытый край. Не зря К.Ф. Рылеев назвал Сибирь «страной изгнанья» [8, с. 6]. Сибирская ссылка с конца XVI в. применялась как кара против политических противников и как милость по отношению к ним взамен более сурового наказания, как мера обеспечения внутренней безопасности государства и как средство заселения отдаленных сибирских территорий.

Первое и главное отличие Сибири от Европейской России декабристам виделось, конечно, в отсутствии крепостного права. Следствием этого стала относительная зажиточность и самостоятельность местных крестьян, на что революционеры в своих мемуарах довольно часто обращали внимание. Декабристы придерживались идеи о том, что 
крепостничество создает дополнительный разрыв между сословиями. Отмечая контраст между унизительным крепостным «рабством» в коренной России и отсутствием такового в Сибири, А.М. Муравьев указывал, что даже незавидное положение прибывающих в Сибирь ссыльнопоселенцев из крепостных крестьян в свете обретаемого ими блага личной свободы много лучше «участи русских рабов», особенно когда первые к тому же «благодаря своему доброму поведению и настойчивости... устраиваются довольно сносно» и даже «становятся богатыми» [11, с. 139].

Н.В. Басаргин утверждал, что отсутствие крепостной зависимости положительно влияет на благосостояние сибирских крестьян, которых сам декабрист характеризовал как народ достаточно «смышлёный и зажиточный» [2, с. 212]. Подтверждение этому мнению можно найти и в записках И.И. Пущина, отмечавшего определенную образованность сибиряка, а также меньшее социальное расслоение в крае, препятствующее «большой нищете» [14, с. 207]. Нельзя, однако, согласиться с утверждением ряда исследователей об идеализации сибиряков декабристами, и прежде всего крестьянства [17, с. 86]. Как вдумчивые наблюдатели они отмечали и негативные стороны сибирской жизни. В.К. Кюхельбекер, в частности, выделял в ней следующие господствующие пороки: пьянство, распутство, склонность к обману. Н.В. Басаргин, служивший в 1848-1857 гг. в Ялуторовске, с сожалением писал о чиновничьем произволе как исходной причине многих из этих народных пороков: «крестьяне, которые наиболее терпят от него (лихоимства чиновников), так им заражены, что когда кто-нибудь из них поступит на общественную должность в своей волости, то необходимо становится отъявленным взяточником и готов всеми средствами притеснять своих собратьев» [2, с. 212].

Г.С. Батеньков отмечал, что в Сибири имеются «обширные пустыни, до которых еще не коснулась рука работника и в которых без пользы погибают многие естественные произведения» [17, с. 98]. В деревне присутствовала дифференциация по имуществу, кабальные отношения процветали, а культура грамотного землепользования не существовала в виду отсутствия средств и примитивных орудий труда. Пользуясь своими накоплениями, богатые крестьяне смогли сами поставить бедных в зависимость, «давая крестьянину, в нужде, деньги на уплату повинностей и заставляя его расплачиваться потом вдвое и втрое работою» - писал Д. Завалишин [17, с. 63].

Представляет интерес и отношение декабристов к проблеме статуса Сибири в составе Российской империи. Мысль о целесообразности предоставления региону областной самостоятельности фиксируется в «Русской правде» П.И. Пестеля. Он предлагал, в частности, разделить Россию на 10 областей, одной из которых предполагалось сделать Сибирь. По «Конституции» Н.М. Муравьева российское государство должно было делиться на ряд самоуправляющихся «держав», в том числе «Обийскую и Ленскую» [16, с. 19].

Не были обойдены декабристами и параллели между освоением Сибири и Североамериканского континента. Еще в 1920-х гг. М.К. Азадовский подметил, что декабристы (Н.В. Басаргин, Н.А. Бестужев, И.И. Пущин, А.Е. Розен, В.И. Штейнгель) пытались сопоставлять Сибирь с Соединёнными Штатами Америки [1, с. 6-8], в том числе с точки зрения политического развития. Находясь в Сибири, Н.И. Бестужев и М.А. Фонвизин переводили главы из книги А. де Токвиля «О демократии в Америке», интересуясь историей колонизации Северной Америки [6]. И.И. Пущин верил в возможность самостоятельного существования региона и необходимость отделиться от метрополии (России), подобно тому, 
как в свое время американские колонии отделились от Англии. Такой путь должен был помочь «подвинуть ее [т. е. Сибирь - H.C.] вперед от России» [14, с. 206]. В письме от 5 марта 1845 г. он отмечал: «Я не иначе смотрю на Сибирь, как на Американские Штаты. Она могла бы тотчас отделиться от метрополии и ни в чем не нуждалась бы - богатая всеми дарами природы. Измените несколько постановления [законы - C.H.], все пойдет улучшаться» [14, с. 206]. Такое же мнение разделяется и А.Е. Розеном. Он проводил своеобразную параллель между ссыльными и беглецами в Сибири с различными авангардными «политическими и религиозными» изгнанниками Северной Америки.

Декабристы первыми поставили вопрос о колониальном положении Сибири в составе Российской империи, причем в их позициях уже наглядно представлены позднейшие различия в трактовках колониальности. По мнению Н.А. Бестужева, Сибирь - «колониальная страна, которую осваивали народы России, русская земля», т. е. колония не столько завоеванная, сколько переселенческая. В отличие от него Г.С. Батеньков рассматривал Сибирь, как типичную, т. е. угнетаемую метрополией, колонию, характерными признаками которой являлись слабая заселенность и эксплуатация сырьевых богатств [18, с. 75]. М.С. Лунин, критикуя политику правительства, отмечал, что даже «новые ресурсы, которые представляет Сибирь, вливающая в оборот свое золото», бездарно расточаются правительством без всякой пользы для «общественного благополучия» [9, с. 299].

Многие впечатления декабристов о Сибири можно было отнести к разряду отрицательных. Лучше всего эмоционально их тяжелое состояние описывал М.С. Лунин. По его мнению, невежество местного населения и суровость климата изглаживали в умах бывшей интеллигенции всякий «тип изящного». Яркие впечатления и грациозность воображения сменялись здесь «спокойствием и скукой» [9, с. 54].

Ссыльные декабристы указывали на низкий уровень развития производительных сил, отсутствие обрабатывающей промышленности, произвол администрации, негативное воздействие штрафной колонизации в Сибири. Отмечая отрицательное влияние каторги и ссылки на состояние общества, они в тоже время показывали бездеятельность и беспомощность местной сибирской власти. Центру якобы были глубоко безразличны подлинные нужды и перспективы развития региона, он отмахивался от решения проблем, тяготивших население края [7, с. 273].

Некоторые декабристы в этой связи пытались адаптировать окружающее их пространство под свои воззрения и идеалы, как было в случае с И.Д. Якушкиным и его школой, в которой ученикам рассказывалось о гражданских свободах, а также М.С. Лунин, который продолжал в период ссылки распространять свои противомонархические воззрения.

Отмечалось бедственное положение ссыльнокаторжных. Информация об этом присутствует в мемуарах декабристов во многом из-за их пребывания на Петровском чугуноплавильном заводе, где ссыльные являлись большинством. М.А. Бестужев, например, рассказывал о труде приписанных к заводу крестьян, которые были «обречены на участь, еще горшую каторжной... Я видел собственными глазами, как 75-летний седой старик (Старченко), слесарь, умер или, точнее, угас, работая у своих тисков» [4, с. 166].

Н.В. Басаргин утверждал о «неестественности» положения этих людей, полностью отвергнутых обществом. Главная проблема виделась в зависимости благосостояния этого слоя от личностей и предпочтений начальства. Если управляющий обращал внимание на материальный быт и пытался его улучшать, то многие ссыльные обзаводились семьями и 
вели хозяйство. Однако в остальных случаях, «проводя целые дни в тяжкой работе, в душном, грязном остроге, без одежды зимой и летом, питаясь так, чтобы не умереть только с голоду», людей ставили в такое положение, при котором бегство могло стать одним из наименее тяжелых их преступлений [4, с. 218].

К таким же выводам приходил М.С. Лунин в письмах к сестре Екатерине Уваровой. Он высказывал весьма гуманную и прогрессивную идею: «Смерть его (осужденного) так же важна, как и жизнь судьи». Декабрист отмечал варварские консервативные начала многих мер, направленных против осужденных законом людей [9, с. 37]. Продолжая эту мысль, мы можем утверждать и о слабой развитости инфраструктуры полицейской охраны региона. У власти, в принципе, не было возможностей направлять людей на поиски «беглецов» в виду и ограниченных ресурсов, и огромных территорий. Поэтому на помощь приходили коренные жители, которым «дозволялось ловить ссыльного и в случае сопротивления убивать его» за вознаграждение в размере 10 руб. ассигнациями [2, с. 359].

Наконец, Н.В. Басаргин в своих «Записках» высказал мысль о необходимости поддерживать охрану личных прав и защиту частной собственности. На тот момент, сам декабрист это подчеркивает, «любые гражданские судебные процессы могли растягиваться на срок более 10 лет и получалось, что расходы на судебные тяжбы иногда не приносили никакой выгоды» [2, с. 204]. Уголовные дела, по его мнению, также подвержены этой проблеме.

Для развития края Н.В. Басаргин предлагал обширный ряд мер:

А) Учреждение наместничества, которое обладало бы самостоятельностью в вопросах административных распоряжений. Расширение прав определенных лиц в частных случаях достаточно легко объясняется тем фактом, что сами наместники должны были ожидать разрешения властей в попытках любых изменений, а генерал-губернаторы чаще всего не решались на большие преобразования.

Б) Учреждение двух департаментов Сената - «гражданского и уголовного».

В) Преобразования экономического пространства на территории Сибири, которые должны были способствовать развитию рыночных отношений и предпринимательской инициативы. Дело в том, что экономическая система Сибири страдала от недостатка капиталов, которые переводились их владельцами сразу в Европейскую часть России, и необходимых специалистов. Учреждение высших учебных заведений на территории Сибири, позволило бы организовывать подготовку нужных кадров для местного производства. Более того, как живущим на этой территории, им было бы легче ориентироваться в ее нуждах и потребностях. Эта идея была высказана практически за полвека до организации первого высшего учебного заведения в Томске. Таким образом, хотя большинство предприятий были добывающего типа, но, как считал Н.В. Басаргин, возможно развитие в Сибири и других производств [2, с. 205].

H.В. Басаргин видел перспективы развития торговых отношений в крае. Подтверждение этого мнения находим и у А.Е. Розена, оставившего важные свидетельства об одной из курганских ярмарок. Помимо детального ее описания, можно увидеть и интересные особенности местной торговли: динамичность сделок; специфика использования бумажных и медных денег; любовь торговаться и др. [13, с. 282].

Н.В. Басаргин, в свою очередь, утверждал, что торговая политика в регионе была чрезвычайно устаревшей в виду слабого развития инфраструктуры и внутренних путей 
сообщения. В пример он приводит ситуацию, сложившуюся в Тобольской губернии в 1850 г., когда цена на зерно была крайне низкой, что повлекло за собой огромные убытки земледельцам, в то же время в Красноярске ценовая политика на хлеб «разоряла даже золотопромышленников» [2, с. 208].

В письмах Борисовых утверждается, что Сибирь страдает от неудобств перевозок, но при этом способна сделать жизнь крестьянина не только безбедной, но и богатой. В доказательство они приводят факты о том, что все «здешние богачи» занимались сначала работой продавца в купеческих лавках, а потом разбогатели на внутренней торговле, которая, по словам братьев, «может быть в некоторых отношениях выгоднее внешней» с Китаем [12].

Все вышеперечисленные примеры свидетельствуют, по мнению декабристов, о слабом понимании центральной властью особенностей региона. Пытаясь ввести в Сибири порядки, установленные на территории Европейской России, государство «создавало лишь больше неразберихи и недовольства», как указывал декабрист Е. Оболенский, «у нас чистая демократия не мыслима без чистого деспотизма» [13, с. 68].

Н.В. Басаргин в своих «Воспоминаниях», описывая природу, которая в Сибири «величественна» [3], отмечал также разнообразие ее животного и растительного мира. Отдельно характеризуется уникальный вид прибрежных скал Забайкалья, похожих на «фантастическую архитектуру», а также многообразие цветов, которым «место и в оранжереях». Описывая природу Забайкалья, декабрист говорит о впечатлениях, «которые никогда не изгладятся» из памяти, настолько сильно они поражали воображение [2, с. 185]. Такие же мысли возникли у А.Е. Розена, он сравнивал дальние «гранитные» холмы, виднеющиеся на горизонте с «древними замки с башнями» [15, с. 254].

Интересны также выводы Ф.Б. Вольфа, сделанные в письмах к И.Д. Якушкину. Автор, анализируя географию Забайкальского региона, отмечал специфику болотистой земли, где присутствовали признаки текучей воды, а также остатки «голышей» (гладких камней) гранитного происхождения. Сам автор относит их к местности Байкала и Ангары. Декабрист делает вывод: «Все это место, вероятно, еще в неотдаленные времена было под водою» [10, c. 171].

Братья Борисовы писали своим сестрам об обилии болот в крае и «сухом и здоровом климате», доказывали возможность выращивания обильных «хлебных растений и почти всех огородных овощей» [12, с. 179]. К таким выводам декабристы пришли на основе свидетельств «туземцев», однако даже хлебные товары соседних деревень, по мнению Борисовых, доказывают, что климат, земля и почва благоприятно влияют на земледелие в Сибири. Важность наличия скота объясняется тем, что даже при самом скромном содержании, овцы способны приносить существенную часть доходов: «при вольных пастбищах, весьма прибыльно» [12, с. 180].

Н.В. Басаргин сообщал о скудном заработке с хлебопашества в Западной Сибири, вследствие дешевой стоимости хлеба, жизнь таких земледельцев могла стать безбедной только в случае занятия ремеслами или «услужением» [2, с. 352].

Первоначально положительную оценку перспектив в земледелии региона давал и Н.А. Бестужев. В первом письме из Селенгинска он уверял своего брата Петра в необычайной «хлебородности» местности. Однако уже через год он делает вывод о том, что качество целинной земли падает по причине регулярных засух: «Болота высохли, речки обмелели, 
источники иссякли совершенно, дожди стали редки и хлеб родится ныне только в смочные годы, тогда как прежде, урожаи почти были баснословные...» [5]. Такие первые неудачи могли стать серьезным ударом для человека, который был убежден, что земледелие - это основной источник народного богатства, и что аграрному успеху во всей России мешает только рабство [4, с. 119]. Таким образом, оценки декабриста потенциала земледелия на территории Сибири изменились, т. к. суровость климата ставила крестьян - земледельцев в тяжелое экономическое положение. Именно поэтому братьями делается вывод о важности содержания скота в Сибири. По этому пути пошел и сам Н.А. Бестужев, занявшись разведением овец. В отношении Забайкалья Н.А. Бестужев писал, что обыденно здесь даже для бедного населения иметь лошадь, коров, овец. Это связано с тем, что скот может питаться всю зиму подножным кормом, который не скрывается за толстым слоем снега. Скот в крае кормят сеном лишь во время заморозков, чтобы обеспечить поддержку «естественной теплоты» [5].

Позднее декабристы отмечали огромные ресурсы, за счет которых Сибирь может существовать самостоятельно, т. к. «богата всеми дарами царства» [14, с. 206]. По этому вопросу высказывался М.А. Бестужев-Марлинский, отмечая обилие природных возможностей в Сибири, что позволяет ей стать промышленным регионом, «страной фабрик и заводов» $[8$, с. 7$]$.

В оценках декабристами природно-географических условий Сибири часто подчеркивалась величественность, возвышенность, необъятность и власть природы над судьбами людей. Весенний гололед, зимний буран могли повлечь за собой гибель сотен голов скота. Низкий уровень медицины также делал животных и людей уязвимыми. Слабость человека по сравнению с суровой природой - один из главных мотивов произведений декабристов. В их записках просматривается достаточно четкая линия, когда первоначальное восхищение природой, ресурсами Сибири и ее богатствами, перспективными возможностями в сельском хозяйстве сменяется все более осторожными утверждениями.

Сами декабристы были людьми творческими, поэтому многие их первоначальные впечатления о Сибири нашли отражение в картинах, стихах, личных записях. Многим еще на каторге пришлось переквалифицироваться из художников, поэтов и ученых в слесарей, токарей, механиков и педагогов и поделиться своими знаниями с собратьями. Многие были не готовы к новым условиям и часто терпели поражения в своих начинаниях, как, например, братья Бестужевы, которым пришлось искать различные способы поиска заработать себе на хлеб.

Декабристы видели будущее края в наращивании производительных сил и налаживании инфраструктуры региона, что позволило бы ему выйти на одну ступень с центральной Россией. Их просветительская работа и критика местной формы управления показали, что изменения этому краю необходимы. Они указывали, что активному развитию Сибири мешают злоупотребления и непонимание властями (от мелких чиновников до генерал-губернаторов) культурных особенностей региона и его специфики. 


\section{КУЛЬТУРА. НАУКА. ОБРАЗОВАНИЕ}

\section{Литература}

1. Азадовский М.К. Странички краеведческой деятельности декабристов в Сибири. Иркутск: Восточно-Сибирское книжное издательство, 1925. 48 с.

2. Басаргин Н.В. Воспоминания, рассказы, статьи. Иркутск: Восточно-Сибирское книжное издательство, 1988. 544 с.

3. Басаргин Н.В. Записки Н.В. Басаргина / Ред. и вступ. ст. П.Е. Щеголева. Петроград, 1917.

4. Бестужев Н.А. Статьи и письма. М.; Л.: изд-во политкаторжан, 1933. 258 с.

5. Бестужев Н.А. Письма из Сибири: Вып. 1. Селенгинский период 1839-1841 / ред. и прим. М.К. Азадовского и И.М. Троцкого. Иркутск: издание Иркутской секции научных работников, 1929.

6. Болховитинов Н.Н. Декабристы и Америка // Вопросы истории. 1974. № 4. С. 96-97.

7. Дамешек Л.М., Ремнев А.В. Сибирь в составе Российской империи. М.: Новое лит. обозрение, 2007. $368 \mathrm{c}$.

8. Жеребцов Б.И. Старая Сибирь в воспоминаниях современников. М: Издательство Юрайт, 2019. 266 с.

9. Лунин М.С. Сочинения, письма, документы. Иркутск: Восточно-Сибирское книжное издательство, 1988. $566 \mathrm{c.}$

10. Лушников Г. Декабрист Ф.Б. Вольф // Декабристы в Сибири. Новосибирск: Новосибирское областное государственное издательство, 1952. С. 165-180.

11. Мемуары декабристов. Северное общество. М.: МГУ, 1981. 400 с.

12. Письма братьев Борисовых, 1838-1841 гг. // Декабристы о Бурятии. Улан-Удэ, 1975. C. $178-196$.

13. Письма Е. Оболенского к М.И. Муравьеву-Апостолу, 1858-1865. Декабристы: неизданные материалы и статьи. М.: Всесоюзное общество политических каторжан и ссыльно-поселенцев, 1925. 117 с.

14. Пущин И.И. Записки о Пушкине. СПб.: Академический проект, 1998. 577 с.

15. Розен А.Е. Записки декабриста. СПб.: Общественная польза, 1907. 464 с.

16. Сонина Л.В. Обзор основных положений конституционных проектов П.И. Пестеля и Н.М. Муравьева // Челябинск: Вестник Челябинского государственного университета, 2002. № 2. С. 15-23.

17. Шатрова Г.П. Декабристы и Сибирь. Томск: Издательство Томского университета, 1962. $178 \mathrm{c}$.

18. Шатрова Г.П. Декабрист Г.С. Батеньков. Томск: Кн. изд-во, 1960. 91 с.

(С)Сологуб Н.С., 2020 